\title{
Faktor Risiko Kebiasaan Tinggal di Rumah Etnis dan Membuang Dahak Sembarang pada Kejadian TB Paru Di Kabupaten Jayawijaya, Papua
}

\author{
Nofi Yigibalom ${ }^{1}$, Sulistiyani ${ }^{2}$, Nurjazuli ${ }^{2 *}$ \\ ${ }^{1}$ Magister Kesehatan Lingkungan Fakultas Kesehatan Masyarakat Universitas Diponegoro, Semarang \\ 2, Fakultas Kesehatan Masyarakat Universitas Diponegoro, Semarang \\ *Corresponding author: nurjzl_fkmundip@yahoo.co.id
}

Info Artikel : Diterima Agustus 2018 ; Disetujui Februari 2019 ; Publikasi April 2019

\begin{abstract}
ABSTRAK
Latar Belakang: Tuberkulosis (TB) paru masih merupakan masalah kesehatan yang menyebabkan kematian pada jutaan orang setiap tahun. Kabupaten Jayawijaya pada 2016 yang diperiksa dahak sebanyak 301 kasus dengan BTA positifnya 64 kasus bila kondisi ini terus meningkat dan berlanjut setiap tahunnya, maka Kabupaten Jayawijaya akan kehilangan manusia yang produktif. Penelitian ini bertujuan menganalisis hubungan antara kebiasaan tinggal di rumah etnis dan membuang dahak sembarang dengan kejadian TB paru di Kabupaten Jayawijaya.

Metode: Jenis penelitian ini adalah penelitian stu dyobservasional analitik dengan pendekatan case control. Subjek penelitian adalah 100 responden, yang terdiri dari 50 kasus terdiagnosis TB paru BTA positif dan 50 kontrol yang terdiagnosis BTA negatif. Pengumpulan data: wawancara, observasi langsung dan pengukuran. Analisis statistik dilakukan menggunakan uji Chi square dengan nilai $\mathrm{p}<0,05$.

Hasil: Hasil Analisis univariat pencahayaan alami dalam menunjukkan rumah rata-rata kasus 23,95 lux dan kontrol 24,20 lux, kelembaban rumah rata-rata 52,38\%, kontrol 51,59\%, suhu rumah rata-rata kasus $27,49^{\circ} \mathrm{C}$,kontrol $27,26^{\circ} \mathrm{C}$. Analisis bivariat menunjukkan ada hubungan kebiasaan tinggal dirumah etnis honai dengan $\mathrm{OR}=2,667$ dan kebiasaan membuang dahak sembarang dengan $\mathrm{OR}=4,750$.

Simpulan: Kebiasaan membuang dahak sembarang, dan kebiasaan tinggal di rumah etnis merupakan faktor risiko kejadian TB paru. Maka perlu adanya sosialisasi terkait faktor risiko kejadian TB terhadap penderita dan masyarakat umum, serta perlu adanya perbaikan lingkungan fisik rumah dan sanitasi rumah.
\end{abstract}

Kata Kunci : Faktor risiko; Rumah etnis; Perilaku; TB paru

\footnotetext{
ABSTRACT

Title: Risk Factors For Habitual Living in Ethnic House and Sputum Spit the Pulmonary TB Jayawijaya District, Papua

Background : Tuberculosis of the lung is still a health problem that causes death to millions of people every year. Jayawijaya in 2016 examined 301 sputum smear positive cases with 64 cases if this condition continues to increase and continues each year, then the Jayawijaya Regency will lose a productive human being. This study aims to analyze the relationship between ethnic home stay habits and throw sputum arbitrarily with the incidence of pulmonary TB in Jayawijaya District.

Methods: This research is an observational analytic study with case control approach. The subjects were 100 respondents, consisting of 50 cases diagnosed with positive smear pulmonary tuberculosis and 50 controls diagnosed with smear negative. Data collection: interviews, direct observation and measurement. Statistical analysis was performed using Chi square test with $p$ value $<0,05$.

Results: The results of the univariate analysis showed that natural lighting in the house the average cases of 23,95 lux and control 24,20 lux, the average humidity of the house was 52,38\%, control $51,59 \%$, the average house temperature was $27,49^{\circ} \mathrm{C}$, control $27,26^{\circ} \mathrm{C}$. Bivariate analysis showed that there was an association of habitual residence of ethnic homes honai with $O R=2,667$ and spiraling habit of spitting with $O R=4,750$
} 
Conclusion: The habit of sputtering any sputum, and the habit of living in ethnic homes is a risk factor for pulmonary TB incidence. So the need for socialization related risk factors for TB incidence of patients and the general public, and the need for improvement of the physical environment of home and sanitation.

Keywords : Risk factors; Ethnic House; Behavior; Pulmonary TB

\section{PENDAHULUAN}

Tuberkulosis (TB) paru tetap masih menjadi masalah kesehatan global dengan beban penyakit yang sangat besar.TB Paru merupakan penyakit infeksi yang disebabkan oleh Mycobacterium tuberculosis yang pada umumnya mempengaruh iparu-paru dan penyebab utama kematian pada jutaan orang setiap tahun di seluruh dunia setelah HIV. ${ }^{1}$ Penularannya bersumber dari penderita TB BTA positif melalui percikan dahak yang dikeluarkannya melalui batuk dan bersin yang mengandung infeksius. ${ }^{2}$ World Health Organization (WHO) menyatakan bahwa situasi Tuberkulosis (TB) paru mengalami kegawatan terutama karena epidemi HIV/AIDS dan kasus resistensi obat TB paru. ${ }^{3}$

WHO dalam Global Tuberculosis Report tahun 2015 menyebutkan bahwa TBdiperkirakan masih menyerang 9,6 juta orang dan menyebabkan 1,2 juta kematian padatahun $2014^{3}$ dan 2015 mencapai 10,4 kasus baru, yang di perkirakan 1,8 juta kematian yang sebabkan oleh TB paru. ${ }^{1}$ India, Indonesia dan China merupakan negara dengan penderita tuberculosis paru terbanyak dari seluruh penderita di dunia. ${ }^{3} \mathrm{Hampir} 75 \%$ penderitaTB paru adalah kelompok usia produktif secara ekonomis ( $15-50$ tahun). Seorang penderitaTB paru dewasa diperkirakan akan kehilangan rata - rata waktu kerjanya 3 - 4 bulan, hal tersebut akan berakibat pada kehilangan pendapatan tahunan rumah tangganya sekitar $20-30 \%{ }^{4}$

Hasil Riskesdas tahun 2013, menyebutkan bahwa prevalensi TB berdasarkan diagnosa sebesar $0,4 \%$ dari jumlah penduduk.Menurut provinsi, prevalensi TB paru tertinggi berdasarkan diagnosis yaitu Jawa Barat sebesar $0,7 \%$, DKI Jakarta dan Papua masing-masing sebesar $0,6 \%$. Sedangkan provinsi Riau, Lampung, dan Bali merupakan provinsi dengan prevalensi TB paru terendah sebesar $0,1 \%{ }^{3,4}$ Kasus berdasarkan jenis kelamin, laki-laki lebih tinggi dari perempuanya itu 1,5 kali dibandingkan pada perempuan untuk seluruh Indonesia dan proporsi penderita TB paru berdasarkan profil kesehatan Indonesia tahun 2015, menyebutkan bahwa proporsi pasien TB paru terkontaminasi diantara semua pasien TB paru mencapai $57,1 \%$. sedangkan papua sendiri baru mencapai 37,3\%. ${ }^{5}$

Kabupaten Jayawijaya merupakan salah satu kabupaten dari 29 kabupaten kota yang mengalami peningkatan kasus TB paru. Jumlah kasus pada tahun 2015 terdapat 334 kasus untuk semua tipe penderita dengan BTA positif 83 kasus dan tahun 2016, 301 kasus dengan BTA positif sebanyak 64 kasus. Angka kesakitan dan kematianpun semakin meningkat dan dampak dari kesakitan ini mempengaruhi produktifitas dari masyarakat dalam memenuhi kebutuhan secara ekonomi menurun. ${ }^{6}$

Faktor-faktor yang menjadi penyebab terjadinya tranmisi TB paru adalahfaktor risiko lingkungan fisik rumah. Menurut Ayomi C.A (2012) beberapa faktor risiko lingkungan fisik rumah seperti luas ventilasi kamar tidur, suhu udara kamar, dan jenis lantai. Namun ada hubungan bermakna juga dengan jenis rumah, pencahayaan alami kamar tidur,adanya sinar matahari langsung dalam rumah, luas ventilasi rumah, luas ventilasi kamar tidur, kelembaban udara kamar, dan jenis lantai rumah dan secara spasial menunjukkanbahwa karakteristik suhu udara, kelembaban,kecepatan angin dan ketinggian juga mempengaruhi penyebaran kasus TB paru. ${ }^{?}$

Menurut Sayuti. J (2013) bahwa faktor risiko yang menyebabkan kejadian TB paru adalah penggunaan bahan kayu bakar untuk memasak dan paparan asap rokok dalam serumah. ${ }^{8}$ Khaliq, dkk (2015) juga menyebutkan bahwa faktor lingkungan fisik rumah berpotensi dapat meningkatkan kejadian TB paru seperti kepadatan hunian, ventilasi rumah, dinding rumah, lantai rumah ,keberadaan jendela, luas kamar, penggunaan bahan bakar dan faktor lingkungan sosial juga menjadi faktor terjadinya peningkatan kasus TB paru seperti keadaan sosial ekonomi, ${ }^{9}$ serta faktor-faktor bersumber individu lainnya seperti jenis kelamin, status perkawinan, penyakit koinfeksi, kontak serumah, merokok, minum-minuman, jenis kelamin, status perkawinan, status gizi, umur, pendidikan dan jenis pekerjaan. ${ }^{10}$

Rumah yang pada prinsipnya berfungsi sebagai tempat tinggal atau hunian untuk berlindung. Rumah dengan kondisi yang tidak memenuhi syarat kesehatan tentu dapat menjadi media terjadinya TB paru. ${ }^{11}$ Lingkungan rumah merupakan salah satu faktor yang memberikan pengaruh besar terhadap status kesehatan penghuni, dimana kuman tuberculosis dapat hidup selama 1-2 jam bahkan sampai beberapa hari hingga berminggu-minggu tergantung pada ada tidaknya sinar ultraviolet, ventilasi yang baik, kelembaban, suhu rumah dan kepadatan penghuni rumah. ${ }^{12}$

Kondisi ekonomi yang rendah membuat sebagian besar masyarakat memiliki rumah yang semi permanan dan tidak permanan yaitu rumah etnis sesuai kondisi daerah yang beriklim dingin. Rumah etnis tersebut tidak memiliki jendela, ventilasi silang dan pintu yang kecil sehingga kondisi dalam rumah suhunya panas, gelap dan lembab. (tidak memenuhi syarat) rumah sehat sehingga perlu dilakukan kajian mengenai faktor risiko tinggal di rumah etnis dan membuang dahak dengan kejadian TB paru. 


\section{MATERI DAN METODE}

Penelitian ini merupakan penelitian study observasional analitik dengan rancangan pendekatan case control. Populasinya adalah semua masyarakat yang berdomisili di wilayah kerja puskesmas Wamena Kota dan puskesmas Asologaima Kabupaten Jayawijaya, yang telah diperiksa dan didignosis oleh dokter atau petugas kesehatan dengan hasil TB paru BTA positif melalui hasil laboratorium di layanan setempat. Sampel pada kelompok kasus adalah sampel yang dipilih dari masyarakat/populasi yang ada di wilyah kerja puskesmas Wamena Kota dan puskesmas Asologaima, pasien yang telah didiagnosis oleh dokter atau petugas kesehatan yang menderita TB paru BTA positif,yang berusia 15 tahun katas melaui pemeriksaan laboratorium. Kelompok kontrol adalah sampel yang dipilh dari masyarakat/populasi studi melalui pemeriksaan dokter dan petugas kesehatan yang didiagnosis hasil laboratorium TB paru BTA negatif, tidak memilik tanda dan gejala riwayat TB paru yang benar-benar sehat, yang ada di wilayah puskesmas Wamena Kota dan puskesmas Asologaima, berusia 15 tahun keatas. Pada kelompok kontrol dipilih dengan sederhana dan masih dalam satu wilayah kerja puskesmas dengan kasus.

Subjek penelitian adalah 100 responden, yang terdiri dari 50 kasus terdiagnosis TB paru BTA positif melalui hasil laboratorium dan 50 kontrol yang terdiagnosis BTA negatif melalui hasil laboratorium. Pengumpulan data dilakukan melalui wawancara, observasi langsung dan pengukuran. Data dianalisis secara deskriptif statistik dilakukan dengan menggunakan uji Chi square.

\section{HASIL DAN PEMBAHASAN}

\section{Analisis Univarit}

Tabel 1 menunjukkan bahwa hasil analisis secara deskriptif pada kasus kontrol dimana pada faktor pencahayaan alami dalam rumah, kelembaban dan suhu dalam rumah dengan rata-rata presentase pencahayaan dalam rumah 23,95 lux dan pada kelompok kontrol 24,20 lux. Kelembaban rata-rata dalam rumah pada kelompok kasus rata-rata 52,38\%, sedangkan pada kontrol rata-rata 51,59\%. Rata-rata suhu dalam rumah pada kelompok kasus $27,49{ }^{\circ} \mathrm{C}$, sedangkan pada kelompok control dengan suhu dalam rumah $27,27^{\circ} \mathrm{C}$.

Tabel 1. Gambaran Faktor Risiko Lingkungan Rumah di Wilayah Kerja Puskesmas Wamena Kota dan Asologaima Kabupaten Jayawijaya

\begin{tabular}{|c|c|c|c|}
\hline \multirow{2}{*}{$\begin{array}{c}\text { Pencahayaan, Suhu, ,Kelembaban } \\
\text { Dalam Rumah }\end{array}$} & \multirow[b]{2}{*}{ Deskriptif Statistik } & \multicolumn{2}{|c|}{ Status Responden } \\
\hline & & $\begin{array}{l}\text { Kasus } \\
(\mathrm{n}=50)\end{array}$ & $\begin{array}{l}\text { Kontrol } \\
(\mathrm{n}=50)\end{array}$ \\
\hline \multicolumn{4}{|l|}{ Pencahayaan alami dalam rumah } \\
\hline & - Mean & 23,95 & 24,20 \\
\hline & - Minimum & .02 & ,03 \\
\hline & - Maksimum & 61,64 & 70,00 \\
\hline & - StandarDeviasi & 24,071 & 24,44 \\
\hline \multicolumn{4}{|l|}{ Kelembaban dalam rumah } \\
\hline & - Mean & 52,38 & 51,59 \\
\hline & - Minimum & 40,00 & 26,50 \\
\hline & - Maksimum & 68,20 & 66,10 \\
\hline & - StandarDeviasi & 5,736 & 6,781 \\
\hline \multicolumn{4}{|l|}{ Suhu dalam rumah } \\
\hline & - Mean & 27,49 & 27,26 \\
\hline & - Minimum & 19,00 & 22,10 \\
\hline & - Maksimum & 32,50 & 32,00 \\
\hline & - Standar Deviasi & 2,623 & 1,984 \\
\hline
\end{tabular}

Pada tabel 2 dari hasil analisis secara deskriptif berdasarkan wawancara dan observasi langsung menunjukkan bahwa proporsi responden pada kelompok kasus yang mempunyai kebiasaan tinggal dirumah etnis honai sebanyak 30 orang $(60,0 \%)$ lebih sedikit dibanding pada kelompok kontrol yang mempunyai kebiasaan tinggal dirumah etnis honai sebanyak 40 orang $(80,0 \%)$. Artinya bahwa baik responden pada kelompok kasus dan kontrol samasama mempunyai kebiasaan tinggal dirumah etnis.
Dari hasil wawancara dengan responden bahwa yang mempunyai kebiasaan membuang dahak sembarang tempat, pada kelompok kasus menunjukkan proporsi responden yang mempunyai kebiasaan membuang dahak sembarang (tidak dalam wadah tertutup) sebanyak 38 orang (76\%) lebih besar dibandingkan pada kelompok kontrol sebanyak 20 orang $(40 \%)$.

Hasil analisis deskriptif pada kelompok kasus dan kontrol dapat dilihat lebih jelasnya pada tabel 1 dan tabel 2. 
Tabel 2. Analisis Faktor Risiko Kebiasaan Tinggal Rumah Etnis dan Membuang Dahak Sembarang di Wilayah Kerja Puskesmas Wamena Kota dan Asologaima Kabupaten Jayawijaya

\begin{tabular}{|c|c|c|c|c|c|c|}
\hline \multirow{2}{*}{ No } & \multirow{2}{*}{ Variabel } & \multirow{2}{*}{ Kategori } & \multicolumn{2}{|c|}{ Kasus } & \multicolumn{2}{|c|}{ Kontrol } \\
\hline & & & $\mathrm{n}$ & $\%$ & $\mathrm{n}$ & $\%$ \\
\hline \multirow[t]{3}{*}{1.} & Kebiasaan tinggal di rumah & - Tinggal & 30 & 60,0 & 40 & 80,0 \\
\hline & etnis honai & - Tidak Tinggal & 20 & 40,0 & 10 & 20,0 \\
\hline & & Total & 50 & 100,0 & 50 & 100,0 \\
\hline \multirow[t]{3}{*}{2.} & Kebiasaan membuang dahak & $\begin{array}{l}\text { - Membuang dahak } \\
\text { sembarang }\end{array}$ & 38 & 76.0 & 20 & 40,0 \\
\hline & & $\begin{array}{r}\text { - Tidak membuang } \\
\text { dahak sembarang }\end{array}$ & 12 & 24,0 & 30 & 60,0 \\
\hline & & Total & 50 & 100,0 & 50 & 100,0 \\
\hline
\end{tabular}

\section{Analisis Bivariat}

Berdasarkan hasil analisis bivariat dengan menggunakan uji Chi-square bahwa hubungan kebiasaan tinggal dirumah etnis honai dan membuang dahak sembarang, dengan kejadian TB paru di Kabupaten Jayawijaya di peroleh sebagai berikut :

Kebiasaan tinggal dirumah etnis honai dengan kejadian TB paru diperoleh nilai $p$-value $=0,050$ dengan nila iodds rasio (OR) sebesar 2, 667 dengan 95\% confidence interval (CI) 1,090-6,524. Hasil uji ini menunjukkan bahwa nilai $<0,05$ dengan demikian dapat dinyatakan bahwa tinggal dirumah etnis honai merupakan faktor risiko antara variabel kebiasaan tinggal dirumah etnis honai dengan kejadian TB paru. Besarnya hubungan antara variable kebiasaan tingga ldirumah etnis honai dengan kejadian TB paru dapa dilihat dari nilai OR sebesar 2,667 yang artinya bahwa responden yang mempunyai kebiasaan tinggal dirumah etnis honai memiliki peluang 2,667 kali lebih besar untuk menderita TB paru dibandingkan dengan responden yang tidak mempunyai kebiasaan tinggal dirumah etnis honai.

Penelitian ini sejalan dengan penelitian Naben (2013) secara statistik menyatakan bahwa kebiasaan tinggal di rumah etnis Timor merupakan faktor risiko terhadap kejadian tuberkulosis paru atau ada hubungan antara kebiasaan tinggal di rumah etnis timor dengan kejadian tuberkulosis paru dengan nilai $p$ value $=$ 0,001: OR $=3,8$ dengan demikian bahwa kebiasaan tinggal di rumah etnis timor berisiko 3,8 kali lebih besar untuk dapat menderita tuberkulosis paru. ${ }^{13}$

Menurut Achmadi (2010) faktor lingkungan (kepadatan, lantai rumah, ventilasi, pencahayaan, dan lain-lain) merupakan faktor risiko yang berperan dalam timbulnya kejadian penyakit TB paru, disamping faktor kependudukan (jenis kelamin, umur, status gizi, sosial ekonomi). ${ }^{14}$ Menurut Srivastava, dkk (2015) juga menyebutkan bahwa faktor yang memainkan peran kunci dalam mempercepat perkembangan dan penularan TB secara aktif yaitu faktor kepadatan huni, kurangnya ventilasi, kontak serumah, gaya hidup yaitu merokok, pekerjaan, umur, jenis kelamin, dan juga faktor lain yaitu faktor malnutrisi, kekebalan tubuh, infeksi penyakit lain (AIDS,diabetes), polusi udara selain itu juga faktor genetik dan Migrasi yang disebabkan karena sosial ekonomi. ${ }^{15}$ Hal yang sama juga disebutkan oleh Anggraeni S (2015) dan Oktavia
S,dkk (2016) menyebutkan bahwa kejadian TB paru berhubungan erat dengan umur, pendidikan jenis lantai, kepadatan hunian, kontak penderita, status gizi, ventilasi, kelembaban rumah, intensitas cahaya dan kebiasaan merokok. ${ }^{16,17}$

Begitu pula lingkungan fisik rumah memberi kontribusi bagi derajat kesehatan penghuninya. Rumah etnis honai merupakan rumah etnis yang unik dan menarik, terbuat dari kayu dan jerami atau ilalang. Rumah etnis yang dihuni oleh masyarakat tersebut tidak memenuhi syarat kesehatan karena tidak memiliki jendela, ventilasi udara, lantai tanah dan berdinding kayu yang tidak sesuai standar kesehatan. Ditambah dengan kebiasaan responden membuat perapian didalam honai menyebabkan banyak asap yang tidak dapat keluar, sehingga risiko penularan sangat mudah terjadi dengan responden yang mempunyai kebiasaan tinggal di rumah etnis honai. Rumah merupakan salah satu kebutuhan dasar hidup manusia yang memiliki arti yang sangat penting dalam kehidupan tiap orang disamping kebutuhan sandang dan papan. ${ }^{13}$ tempat tinggal atau rumah yang buruk (kurang baik) dapat mendukung terjadinya penularan penyakit atau gangguan kesehatan diantaranya infeksi saluran pernapasan. Kondisi rumah dapat menjadi salah satu faktor risiko penularan TB paru,atap,dinding dan lantai rumah dapat menjadi tempat perkembangbiakan bakteri. Dinding dan lantai yang sulit dibersihkan menyebabkan terjadinya penumpukan debu, maka akan dijadikan sebagai media yang baik untuk berkembangbiaknya bakteri Mycobakterium tuberculosis. ${ }^{18,19}$

Agar rumah dapat berfungsi dengan baik maka kegunaanya harus didasarkan pada Permenkes No.829/Menkes/SK/VII/1999 tentang Persyaratan Kesehatan Perumahan. Rumah sehat tersebut memiliki syarat antara lain :dapat memenuhi kebutuhan physiologis, psichologis, mencegah penularan penyakit dan dapat mencegah terjadinya kecelakaan. ${ }^{20}$

Kaitannya dengan tinggal di rumah etnis honai dengan kejadian TB paru adalah merupakan pemenuhan kebutuhan cahaya buat penerangan alami sangat ditentukan oleh bentuk rumah yang memiliki pintu jendela, ventilasi yang baik dan memenuhi syarat kesehatan. Baik pintu, jendela dan ventilasi berfungsi sebagai sirkulasi udara dalam rumah agar dalam rumah tidak lagi terasa panas, pengap, disamping itu sinar 
matahari pagi dapat masuk ke dalam rumah sehingga dapat membunuh kuman mycobacterium tuberkulosis, influenza, dan lain-lain. ${ }^{13}$ Untuk mencegah penularan TB paru maka rumah etnis yang ada perlu dimodifikasi dengan tidak menghilangkan struktur bangunan dan culture dari rumah etnis sehingga ada pergantian sirkulasi udara dalam rumah etnis honai, sinar matahari dapat masuk rumah hingga dapat membunuh kuman Mycobaterium tuberculosis serta tidak terjadi penularan TB paru di dalam rumah.

Kebiasaan membuang dahak adalah suatu kegiatan membuang dahak atau ludah yang berasal dari mulut yang dilakukan oleh seseorang. Membuang dahak atau meludah di sembarang tempat dapat meningkatkan penyebaran kuman TB paru, sebab kuman TB dapat hidup dan mempunyai peluang untuk menularkan kuman jika dahak atau ludah dibuang di sembarang tempat. ${ }^{21,22}$

Kebiasaan membuang dahak sembarang dengan kejadian TB paru diperoleh nilai $p$-value $=0,001$ dengan nilai odds rasio (OR) sebesar 4,750 dengan 95\% confidence interval (CI) 2,008-11,236. Hasil uji ini menunjukkan bahwa nilai $p<0,05$ dengan demikian dapat dinyatakan bahwa tidak membuang dahak dalam wadah tertutup merupakan faktor risiko antara kebiasaan membuang dahak sembarang dengan kejadian TB paru. Besarnya hubungan antara kebiasaan membuang dahak sembarang dengan kejadian TB paru dapat dilihat dari nilai OR sebesar 4,750 yang artinya bahwa responden yang mempunyai kebiasaan membuang dahak sembarang atau tidak dalam wadah tertutup memiliki peluang 4,750 kali lebih besar untuk menderita TB paru dibandingkan dengan responden yang tidak mempunyai kebiasaan membuang dahak sembarang atau dibuang dalam wadah tertutup.

Penelitian ini sejalan dengan penelitian yang dilakukan oleh Suluh G (2012) di Kota Kupang menemukan bahwa ada hubungan yang bermakna antara kebiasaan membuang sputum dengan kejadian TB paru BTA $(+)$ dengan nilai $p=0,0001 ; \mathrm{OR}=53,958$ karena nilai $p$ value $<0,05$ dan penelitian yang dilakukan oleh Wulandari (2015) di kabupaten Kendal juga menemukan bahwa ada hubungan yang bermakna antara kebiasaan membuang dahak disembarang tempat mempunyai risiko kejadian TB paru dengan nilai $\mathrm{p}=0,016 ; \mathrm{OR}=4,402$. Peneltian yang dilakukan oleh Manangsang (2016) di Kabupaten Jayawijaya menemukan bahwa perilaku baik sikap dan tindakan berhubungan dengan penularan TB paru. ${ }^{23,24,25}$

Dari pengamatan dan wawancara yang dilakukan pada saat penelitian ditemukan bahwa responden mempunyai kebiasaan membuang dahak tidak pada tempatnya namun dibuang disamping rumah, depan pintu ataupun halaman rumah bagi responden yang mendiami rumah modern sedangkan responden yang mendiami rumah etnis sebagian mempunyai kebiasaan membuang dahak di samping tempat pembuatan api unggun dan juga dibuang disudut rumah etnis dengan membuka ilalang yang dipakai untuk alas duduk. Hal ini memungkinkan dapat menyebabkan terjadi penularan TB paru.

Kebiasaan membuang dahak di sembarang tempat merupakan sumber penularan terjadinya TB paru yang didukung pula oleh faktor lain seperti kepadatan huni, suhu, kelembaban, pencahayaan alami, ventilasi, jenis rumah, jenis lantai, jenis dinding, kebiasaan batuk dan bersin, perilaku merokok, konsumsi alkhol dan penyakit infeksi lainnya serta secara spasial kecepatan angin serta ketinggian juga mempengaruhi penyebaran kasus TB paru juga menjadi factor penularan TB paru atau media berkembangbiaknya bakteri kejadian TB paru. ${ }^{7,18}$

Kaitannya dengan kebiasaan membuang dahak sembarang dengan kejadian TB paru adalah bahwa kebiasaan membuang dahak pada sembarang tempat atau pada tempat terbuka mempunyai peran terhadap terjadinya TB paru karena dapat memungkinkan kuman Mycobacterium tuberculosis akan bertahan hidup diudara beberapa jam selama 20-30 jam kecuali ada sinar matahari (ultraviolet). Hal ini dapat berpotensi menginfeksi seseorang bila droplet tersebut terhirup dan masuk ke dalam saluran pernapasan. Apabila penderita TB paru membuang dahak disembarang tempat misalnya dahak dibuang dalam rumah atau diluar kamar, dibuang di kaleng yang telah diberi lisol ataupun tanpa diberi lisol, maka dengan kondisi suhu dan kelembaban yang sesuai ini dapat bertahan hidup dan berkembang biak, bakteri tersebut akan tetap ada dilingkungan tersebut dan sewaktuwaktu dapat menginfeksi orang yang sehat. ${ }^{26}$ Mycobakterium tuberculosis merupakan bakteri mesofilik yang tumbuh subur dalam temperatur optimum $37^{\circ} \mathrm{C}$ dan tidak dapat tumbuh pada suhu $25^{\circ} \mathrm{C}$ atau lebih dari $40^{\circ} \mathrm{C}$. Bakteri akan mati jika berada dalam lingkungan dengan suhu $6^{\circ} \mathrm{C}$ selama1520 menit atau suhu lebih tinggi dari $60^{\circ} \mathrm{C}$,juga jika terkena sinar matahari langsung selama 2 jam. ${ }^{26}$ Untuk menghindari penularan penyakit TB paru yang disebabkan oleh Mycobaterium tuberculosis, maka perlu hindari kontak antara orang yang sehat dengan dahak yang dibuang oleh penderita.Perilaku penderita dalam hal membuang dahak dapat diubah dengan membuang dahak pada kaleng atau tempat tertentu dengan diberi lisol,dan selalu menjemur alat tidur dibahwa matahari, serta membersihkan lingkungan sekitarnya sehingga penularan TB paru dapat diputuskan. ${ }^{26}$ 
Tabel 3. Hasil Analisis Hubungan menggunakan uji Chi-Square antara Variabel Bebas Dengan Kejadian TB Paru Di Wilayah Kerja Puskesmas Wamena Kota dan AsologaimaKabupaten Jayawijaya.

\begin{tabular}{ccccccc}
\hline & & & \multicolumn{2}{c}{$\mathbf{9 5 \%}$ \% CI } & \multirow{2}{*}{ Keterangan } \\
\cline { 5 - 6 } No & Variabel & p-value & OR & Lower & Upper & \\
\hline 1. & Kebiasaan tinggal di rumah etnis honai & $\mathbf{0 , 0 5 0 *}$ & 2,667 & 1,090 & 6,524 & Signifikan \\
2. & Kebiasaan membuang dahak sembarang & $\mathbf{0 , 0 0 1 *}$ & 4,750 & 2,008 & 11,236 & Signifikan \\
\hline
\end{tabular}

Dari hasil wawancara yang penulis lakukan diperoleh informasi bahwa tokoh masyarakat, tokoh agama dan responden sendiri mengenai rumah etnis, hampir $99 \%$ menyampaikan bahwa rumah etnis honai tidak dapat di ubah bentuk dan strukturnya karena rumah honai tersebut merupakan umah adat yang telah ada sejak dahulu dan daerah di sana beriklim dingin. Dengan melihat kondisi seperti ini maka perlu dilakukan sosialisasi modifikasi rumah etnis honai, dibuat agak tinggi tiangnya tanpa merubah bentuk asli dan dibuat ventilasi berupa jendela pada rumah etnis honai di mana pada saat pagi hari sinar ultra violet dapat masuk ke dalam rumah sehingga dapat mengurangi kelembaban dan terjadi pergantian sirkulasi udara.

\section{SIMPULAN}

Berdasarkan hasil penelitian ini dapat disimpulkan bahwa: hasil analisis univariat pencahayaan alami dalam menunjukkan rumah ratarata kasus 23,95 lux dan kontrol 24,20 lux, kelembaban rumah rata-rata 52,38 \%, kontrol 51,59\%, suhu rumah rata-rata kasus $27,49^{\circ} \mathrm{C}$, kontrol $27,26{ }^{\circ} \mathrm{C}$. Ada hubungan kebiasaan tinggal di rumah etnis ( $p$ value $=0,050)$ dengan nilai $O R=2,667$. Ada hubungan kebiasaan membuang dahak sembarang ( $p$-value $=$ 0,001) dengan nilai $O R=4,750$ dengan kejadian TB paru di Kabupaten Jayawijaya. Diperlukan upaya peningkatan sosialisasi terkait perilaku hidup bersih dan sehat, rumah sehat, perbaikan lingkungan fisik rumah dan sanitasi lingkungan rumah oleh dinas terkait dan kerja sama lintas sektor dalam hal penataan rumah sehat guna memutuskan rantai penularan TB paru.

\section{DAFTAR PUSTAKA}

1. World Health Organization. Global Tuberculosis Report 2016. Switzerland; 2016.

2. Turner RD, Bothamley GH. Cough and the transmission of tuberculosis. Journal Infection Dis. 2015;211(9):1367-72.

3. World Health Organization. Tuberculosis Report . 2015.

4. Kementerian Kesehatan Republik Indonesia. Pedoman Nasional Pengendalian Tuberkulosis. Jakarta: Kementerian Kesehatan RI; 2014.

5. Kementerian Kesehatan Republik Indonesia. Profil Kesehatan Indonesia 2015. Kementerian Kesehatan RI, editor. 2016.

6. Dinas Kesehatan Kabupaten Jayawijaya. Laporan Sistem Informasi Tuberkulosis Terpadu (SITT) Tahun 2014-2016. Wamena; 2017.
7. Ayomi AC, Setiani O, Joko T. Faktor Risiko Lingkungan Fisik Rumah Dan Karakterisik Sebagai Determinan Kejadian penyakit Tuberkulosis Paru Di Wilayah Kerja Puskesmas Sentani Kabupaten Jayapura Propinsi Papua. Jurnal Kesehatan Lingkungan Indonesia. 2012;11 (1):1-8.

8. Sayuti J. Asap Sebagai Salah Satu Faktor Risiko Kejadian TB Paru BTA Positif Analisis Spasial Di Kabupaten Lombok Timur. Semin Nas Informati Medis. 2013;4 (1):13-23.

9. Khaliq A, Khan I H, Akhtar M W CMN. Enviromental Risk Factors and Social Determinants of Pulmonary Tuberculosis in Paksitan. Epidemiologi Open Access. 2015;5:201.

10. Manalu H S P. Faktor- Faktor Lingkungan Yang Mempengaruhi Kejadian TB Paru Dan Penaggulangannya. Jurnal Ekologi Kesehatan. 2010;9 (4):1340-6.

11. Mutassirah, Sulislawati A, Ibrahim AI. Analisis Spasial Kejadian Tuberkulosis di Dataran Rendah Kabupaten Gowa. Hig Jurnal Kesehatan Lingkungan. 2017;3(3):145-51.

12. Notoatmodjo s. Ilmu Kesehatan Masyarakat. Prinsip - Prinsip Dasar. Jakarta: Rineka Cipta; 2003. 329-36.

13. Naben AX, Suhartono, Nurjazuli. Kebiasaan Tinggal di Rumah Etnis Timor Sebagai Faktor Risiko Tuberkulosis Paru. Jurnal Kesehatan Lingkungan Indonesia. 2013;12(1):10-21.

14. Achmadi UF. Manajemen Penyakit Berbasis Wilayah. Jakarta: Penerbit Universitas Indonesia(UI-Press); 2010.

15. Srivastava K, Kant S, Verma A. Role of Environmental factors in Transmission of Tuberculosis. Dyn Hum Heal Dyn Hum Heal. 2015;2 (4):2382-1019.

16. Anggraeni SK, Mursid Raharjo, Nurjazuli. Hubungan Kualitas Lingkungan Rumah dan Perilaku Kesehatan Dengan Kejadian TB Paru di Wilayah Kerja Puskesmas Gondanglegi Kecamatan Gondanglegi Kabupaten Malang 2014. Jurnal Kesehatan Masyarakat . 2015;3 (1):556-68.

17. Surakhmi O, Rini M, Suci D. Analisis Faktor Risiko Kejadian TB Paru di Wilayah Kerja Puskesmas Kertapati Palembang. Jurnal Ilmu Kesehatan Masyarakat. 2016;1.

18. Heriyani Farida, Sutomo Heru A SDY. Risk Factor Of The Incidence Of Pulmonary Tuberculosis in Banjarmasin City,Kalimantan Indonesia. International Journal of Public Health 
Science. 2013;2(1): 1-6.

19. Corburn J, Hilde CB. Slum Sanitation And the Social Determinants of Women's Health In Nairoba Kenya. Journal of Enviromental Public Health. 2015;1:1-6.

20. Departeman Kesehatan RI. Keputusan Menteri Kesehatan RI No.829/MENKES/SK/VII/1999 Tentang Persyaratan Kesehatan Perumahan. Jakarta; 1999.

21. Kotouki A. Gambaran Perilaku Penderita dan Risiko Tuberkulosis BTA Positif dengan Kepatuhan Minum Obat dan Kebiasaan Membuang Dahak Di Wilayah Puskesmas Ciomas Kabupaten Bogor Provinsi Jawa Barat. 2012;

22. Hidayat R, Bahar H, Ismail CS. Skrining Studi Epidemiologi Penyakit Tuberculosis Paru Di Lembaga Pemasyarakatan Kelas II A Kendari Tahun2017. Jurnal Ilmiah Kesehatan Masyarakat. 2017;2 (6).
23. Suluh G D. Analisis Faktor Lingkungan Fiski Dalam Rumah dan Praktik Pencegahan Terhadap Kejadian Tuberkulosis Paru di Kecamatan Kota Lama dan Kecamatan Kepala Lima Kota Kupang. Universitas Diponegoro; 2012.

24. Wulandari AA, Nurzajuli, Adi MS. Faktor Risiko dan Potensi Penularan Tuberkulosis Paru di Kabupaten Kendal, Jawa Tengah. Jurnal Kesehatan Lingkungan Indonesia. 2015;14(1):713.

25. Manangsang F, Arsunan AA, Hatta Mochammad, Nurdin A A AA. Behavior Model Analysis and Risk Factors of Pulmonary Tuberculosis Transmission of Honai Residents in Wamena, Jayawijaya District, Papua. International Journal Science Appl Res. 2016;30 (3): 209-221.

26. Anggraeni S D. Stop Tuberkulosis. Bogor: Penerbit Publishing House; 2011. 1-40. 